\title{
Establishment of an in vitro regeneration system for genetic transformation of selected sugarcane genotypes
}

\author{
S. Ijaz, I.A. Rana, I.A. Khan and M. Saleem \\ Centre of Agricultural Biochemistry and Biotechnology, \\ University of Agriculture Faisalabad, Pakistan \\ Corresponding author: S. Ijaz \\ E-mail: siddraijazkhan@yahoo.com
}

Genet. Mol. Res. 11 (1): 512-530 (2012)

Received November 3, 2011

Accepted January 18, 2012

Published March 6, 2012

DOI http://dx.doi.org/10.4238/2012.March.6.4

\begin{abstract}
A good culture system provides considerable quantities of highly regenerable target tissues. Embryogenic callus cultures are ideal for micro-projectile-mediated transformation, because regenerable cells are not very stable. Effective exploitation of genetic transformation requires good regeneration systems. We selected three sugarcane genotypes for the establishment and optimization of good in vitro regeneration systems, viz., S-2003-us-359, S-2006-sp-30, and S-2003-us-165. Three callus induction media were investigated. These media were composed of Murashige and Skoog (MS) medium salt plus 1,2 , and $3 \mathrm{mg} / \mathrm{L}$ 2,4-dichlorophenoxyacetic acid (2,4-D). Medium with $3 \mathrm{mg} / \mathrm{L}$ 2,4-D gave the greatest mass of embryogenic calli. The calli produced on the three callus induction media were transferred to 18 types of regeneration media (RM1-RM18). They varied with respect to plant growth regulators and sucrose levels but the basal medium was MS. Two levels of sucrose ( 30 and $40 \mathrm{~g} / \mathrm{L}$ ), three levels of 2,4-D $(0.1,0.25,0.5 \mathrm{mg} / \mathrm{L})$ and three levels of 6-benzylaminopurine $(0,0.25$ and $0.5 \mathrm{mg} / \mathrm{L}$ ) were studied in the regeneration media. The effects of callus age on regeneration were evaluated by transferring the calli to regeneration media after 15, 21, 28, and 35 days of culture. The 21-day-
\end{abstract}


old callus of the genotype S-2003-us-359 on RM3 yielded the largest number of plants and was selected as the best for transformation. Six RAPD DNA primers were used to check genetic stability; this medium did not affect the sugarcane genomes.

Key words: 6-Benzylaminopurine; Callus; Sugarcane

\section{INTRODUCTION}

The dismal results of world trade, industrial liberalization and the free market economy have made it extraordinarily difficult for countries like Pakistan to maintain even a low economic profile. At present, our low-tech industrial base is unable to compete in global markets and this problem will be perpetuated into the future. Agriculture is one of the few sectors offering real potential for sustainable growth and could play a key role in helping to build the economy of the country.

Worldwide, sugarcane crop productivity has progressively risen to noteworthy levels in the last century (Keating and Wilson, 1997). Sugarcane is not only a cash crop for Pakistan; it is also the main source of sugar. Our sugar industry and sugar needs are exclusively dependent on the fate of this crop. Efficient photosynthesis and proficient biomass production make this crop a superb target for industrial processing and a significant alternative for animal feed and by-products manufacturing in tropical and subtropical countries. Today there is a vital need to augment sugarcane productivity and enhance quality.

To promote the lucrative sugar industry there is increasing pressure worldwide to boost the productivity of sugarcane. Current development and evolution in biotechnology offer several ways of tackling issues related to the development of novel, high-yielding cultivars (Ellis et al., 2000). Due to its worldwide significance, much attention has been paid to sugarcane crop improvement through plant breeding, and lately through biotechnology. By conventional crossing programs, sugarcane breeding is difficult as backcrossing for the introduction of specific genes is complicated by random genetic rearrangement occurring at meiosis. Without genetic rearrangements, the introduction of specific genes into sugarcane can be achieved through genetic engineering.

Sugarcane breeders have explored potentials to resolve specific defects or to improve a specific desirable trait of highly adapted and genetically balanced sugarcane without involving a sexual cycle. Transgenic plant development (Arencibia et al., 1995) and in vitro selection for disease resistance (Cassells and Jones, 1995) have generated high hopes for desired and efficient enhancement in plant quality. There is ample natural resistance present within the 'Saccharum complex' against various fungal and bacterial pathogens (Hogarth et al., 1997). There is a current need to retain, maintain or introduce resistance against diverse pathogens in the currently cultivated genotypes as well as other valuable sugarcane germplasm with commercial or breeding potential.

Sugarcane is a polysomatic, highly heterozygous crop. This crop is characterized by high levels of polyploidy and frequent aneuploidy (Daniels and Roach, 1987). In sugarcane breeding, the lack of rapid multiplication of clones is a serious bottleneck (Ali and Afghan, 2001). Complex genome, narrow gene pool and poor fertility are the major hurdles for progress in the traditional breeding of sugarcane. Sugarcane germplasm available in Pakistan is 
highly heterogeneous and generally multiplied vegetatively by stem cutting. To speed up the process of sugarcane breeding and commercialization, micro-propagation is the only real solution. Plant tissue culture techniques have become a powerful tool for studying and solving basic and applied problems in plant biotechnology, especially gene introduction (Villalobos, 1987).

Sugarcane biotechnology research began in the 1960s with in vitro plant regeneration research (Heinz and Mee, 1969). Serious efforts to boost production of this food crop by molecular approaches have commenced only in the last two decades. The application of biotechnology research in sugarcane improvement has a considerable impact on agricultural yields and industrial production. Plant tissue culture, molecular biology and plant transformation have been established.

In the case of in vitro propagation, genetic stability is a major bottleneck. Somaclonal variations are known to be exhibited by plantlets derived from tissue culture, which is often heritable (Larkin and Scowcroft, 1981). Various strategies have been employed to check the genetic stability of tissue culture-derived plants (Devarumath et al., 2007). Among these strategies, molecular marker techniques are being extensively employed for the characterization of somaclonal variation at the DNA level (Cloutier and Landry, 1994). To assess somaclonal variation in crop plants, randomly amplified polymorphic DNA (RAPD) analysis is being commonly used (Devarumath et al., 2007). Different studies have revealed that embryogenic culture-derived plants are genetically identical and less prone to genetic changes compared to organogenic culture (Chowdhury and Vasil, 1993). Sugarcane plants, regenerated from embryogenic callus, showed limited polymorphism in RAPD analysis (Taylor et al., 1995), which proves that gross genetic changes are uncommon during the tissue culture process.

For the development of transgenic plants the first step is the development of an efficient in vitro regeneration system in crop plants. Because only a few transformed tissues with foreign DNA survive, we established an in vitro regeneration system in the selected genotypes of sugarcane. On the basis of callus induction and regeneration, the genotype for genetic transformation was selected with the medium of choice. In transgenic plant development, the objective is always that the genetic change would only be the change, which is due to the transgene. The genetic change due to in vitro regeneration was not desired and genetic stability in selected regeneration system is required. That is why we confirmed the genetic stability of selected in vitro regeneration system by using RAPD primers.

\section{MATERIAL AND METHODS}

\section{Collection of plant materials/sugarcane germplasm}

For this study, we selected three elite lines/genotypes, which have excellent agronomic traits but poor resistance against Colletotrichum falcatum, the cause of red rot disease. These selected genotypes were S-2003-us-359, S-2006-sp-30 and S-2003-us-165.

\section{Surface sterilization of explants}

Fresh innermost young leaf rolls of mature sugarcane crop plants were used as explants. These young leaves are surrounded by several tightly packed mature leaves. The top portions of sugarcane were cut and their surface was sterilized with methylated spirit. Then, 
the outermost hard leaves were removed and innermost leaves were transversely sliced into 2-3-mm thick slices with a sterile scalpel and blades and cultured on medium on Petri plates, containing Murashige and Skoog (MS) salt, different levels of sucrose and growth regulators in order to find the optimal one for callogenesis, regeneration, growth, development, and multiplication of the plants (Figure 1). All these operations were done under axenic conditions in a laminar air flow cabinet. Before the start of these operations, all scalpels, blades and forceps were sterilized.

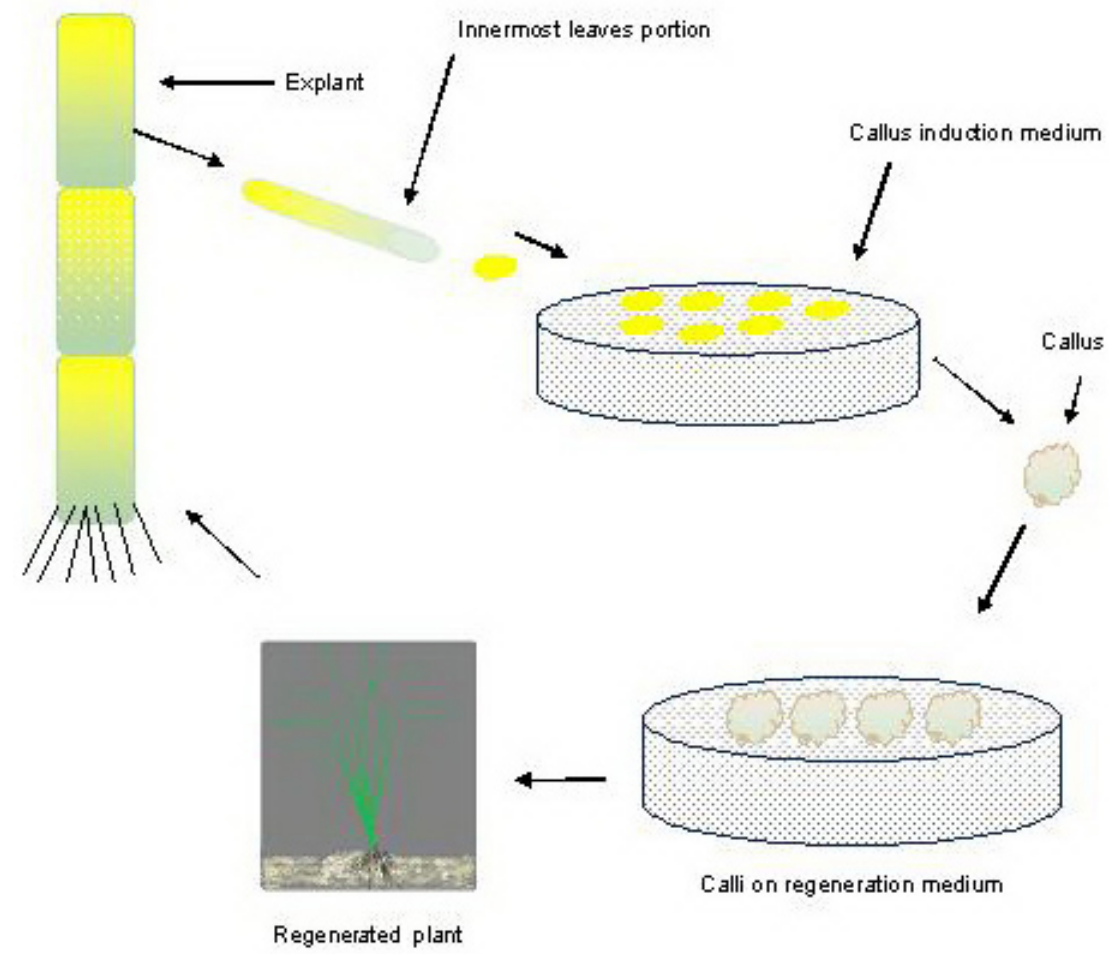

Figure 1. General tissue culture methodology.

\section{Embryogenic callus proliferation}

For callogenesis, three callus induction media (CIM) were studied. These media all contained MS salt, sucrose, myoinositol, nicotinic acid, pyridoxine $\mathrm{HCl}$, thymine $\mathrm{HCl}$, glycine, and Phytagel. The exact concentrations are described in Table 1. Additionally 2,4-dichlorophenoxyacetic acid (2,4-D) levels varied in each medium $(1,2$ and $3 \mathrm{mg} / \mathrm{L})$. Young leaf roll slices of all three genotypes (S-2003-us-359, S-2006-sp-30 and S-2003-us-165) were cultured on these three callus induction media on Petri plates and these Petri plates were kept in the dark and the calli induced were subcultured onto fresh medium after 25 days of culture for further proliferation. The data were taken every week, and five weeks of data were collected. This experiment was repeated four times and on the basis of these data two genotypes were selected for the regeneration experiment (Figure 2). 
Table 1. Callus induction media (CIM) with three levels of 2,4-D.

\begin{tabular}{|c|c|c|c|c|c|}
\hline \multicolumn{2}{|l|}{ CIM1 } & \multicolumn{2}{|l|}{ CIM2 } & \multicolumn{2}{|l|}{ CIM3 } \\
\hline MS salt & $4.33 \mathrm{~g} / \mathrm{L}$ & MS salt & $4.33 \mathrm{~g} / \mathrm{L}$ & MS salt & $4.33 \mathrm{~g} / \mathrm{L}$ \\
\hline Sucrose & $40.00 \mathrm{~g} / \mathrm{L}$ & Sucrose & $40.00 \mathrm{~g} / \mathrm{L}$ & Sucrose & $40.00 \mathrm{~g} / \mathrm{L}$ \\
\hline $2,4-\mathrm{D}$ & $1.00 \mathrm{mg} / \mathrm{L}$ & $2,4-\mathrm{D}$ & $2.00 \mathrm{mg} / \mathrm{L}$ & $2,4-\mathrm{D}$ & $3.00 \mathrm{mg} / \mathrm{L}$ \\
\hline Myoinositol & $0.10 \mathrm{~g} / \mathrm{L}$ & Myoinositol & $0.10 \mathrm{~g} / \mathrm{L}$ & Myoinositol & $0.10 \mathrm{~g} / \mathrm{L}$ \\
\hline Nicotinic acid & $1.00 \mathrm{~g} / \mathrm{L}$ & Nicotinic acid & $1.00 \mathrm{~g} / \mathrm{L}$ & Nicotinic acid & $1.00 \mathrm{~g} / \mathrm{L}$ \\
\hline Pyridoxine $\mathrm{HCl}$ & $1.00 \mathrm{~g} / \mathrm{L}$ & Pyridoxine $\mathrm{HCl}$ & $1.00 \mathrm{~g} / \mathrm{L}$ & Pyridoxine $\mathrm{HCl}$ & $1.00 \mathrm{~g} / \mathrm{L}$ \\
\hline Thymine $\mathrm{HCl}$ & $2.00 \mathrm{~g} / \mathrm{L}$ & Thymine $\mathrm{HCl}$ & $2.00 \mathrm{~g} / \mathrm{L}$ & Thymine $\mathrm{HCl}$ & $2.00 \mathrm{~g} / \mathrm{L}$ \\
\hline Glycine & $4.00 \mathrm{~g} / \mathrm{L}$ & Glycine & $4.00 \mathrm{~g} / \mathrm{L}$ & Glycine & $4.00 \mathrm{~g} / \mathrm{L}$ \\
\hline Phytagel & $2.66 \mathrm{~g} / \mathrm{L}$ & Phytagel & $2.66 \mathrm{~g} / \mathrm{L}$ & Phytagel & $2.66 \mathrm{~g} / \mathrm{L}$ \\
\hline
\end{tabular}

MS = Murashige and Skoog medium; 2,4-D = 2,4-dichlorophenoxyacetic acid.

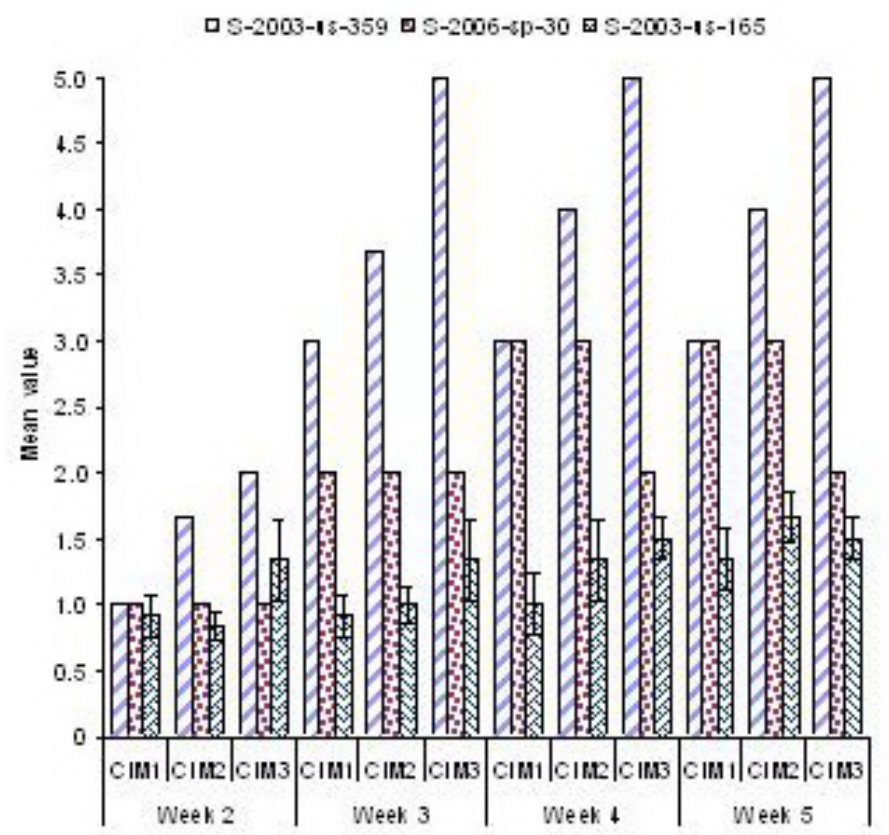

Figure 2. Callus induction in sugarcane genotypes on different callus induction media (CIM) and callus age (in weeks).

\section{Shoot regeneration}

In the regeneration experiment, 18 different regeneration media were studied (details can be seen in Table 2). In the regeneration media there were 2 levels of sucrose (30 and 40 $\mathrm{g} / \mathrm{L}), 2$ levels of 6-benzylaminopurine (BAP; 0.25 and $0.5 \mathrm{mg} / \mathrm{L})$ and 3 levels of 2,4-D (0.1, 0.25 and $0.5 \mathrm{mg} / \mathrm{L}$ ), and 15-, 21-, 28-, and 35-day-old calli of two genotypes (S-2003-us-359, S-2006-sp-30) on three callus induction media were put on these 18 regeneration media and incubated at $26 \pm 1{ }^{\circ} \mathrm{C}$ for 8-16-h dark and light conditions. Developed shoots were shifted to $1 / 2$ MS medium (Table 3) for rooting. Regeneration data were compiled on the basis of the plantlets formed. This experiment was repeated three times (Figure 3A-C and Figure 4). 
Table 2. Regeneration media (RM) with different levels of sucrose and growth regulators.

\begin{tabular}{|c|c|c|c|c|c|c|c|c|c|c|}
\hline & MS salt & Sucrose & 2,4-D & BAP & Myoinositol & Nicotinic acid & Pyridoxine $\mathrm{HCl}$ & Thymine $\mathrm{HCl}$ & Glycine & Phytagel \\
\hline RM1 & $4.33 \mathrm{~g} / \mathrm{L}$ & $40 \mathrm{~g}$ & $0.10 \mathrm{mg} / \mathrm{L}$ & 0 & $0.1 \mathrm{~g} / \mathrm{L}$ & $1 \mathrm{~g} / \mathrm{L}$ & $1 \mathrm{~g} / \mathrm{L}$ & $2 \mathrm{~g} / \mathrm{L}$ & $4 \mathrm{~g} / \mathrm{L}$ & $2.66 \mathrm{~g} / \mathrm{L}$ \\
\hline RM2 & $4.33 \mathrm{~g} / \mathrm{L}$ & $30 \mathrm{~g}$ & $0.10 \mathrm{mg} / \mathrm{L}$ & 0 & $0.1 \mathrm{~g} / \mathrm{L}$ & $1 \mathrm{~g} / \mathrm{L}$ & $1 \mathrm{~g} / \mathrm{L}$ & $2 \mathrm{~g} / \mathrm{L}$ & $4 \mathrm{~g} / \mathrm{L}$ & $2.66 \mathrm{~g} / \mathrm{L}$ \\
\hline RM3 & $4.33 \mathrm{~g} / \mathrm{L}$ & $40 \mathrm{~g}$ & $0.10 \mathrm{mg} / \mathrm{L}$ & $0.25 \mathrm{mg} / \mathrm{L}$ & $0.1 \mathrm{~g} / \mathrm{L}$ & $1 \mathrm{~g} / \mathrm{L}$ & $1 \mathrm{~g} / \mathrm{L}$ & $2 \mathrm{~g} / \mathrm{L}$ & $4 \mathrm{~g} / \mathrm{L}$ & $2.66 \mathrm{~g} / \mathrm{L}$ \\
\hline RM4 & $4.33 \mathrm{~g} / \mathrm{L}$ & $40 \mathrm{~g}$ & $0.10 \mathrm{mg} / \mathrm{L}$ & $0.50 \mathrm{mg} / \mathrm{L}$ & $0.1 \mathrm{~g} / \mathrm{L}$ & $1 \mathrm{~g} / \mathrm{L}$ & $1 \mathrm{~g} / \mathrm{L}$ & $2 \mathrm{~g} / \mathrm{L}$ & $4 \mathrm{~g} / \mathrm{L}$ & $2.66 \mathrm{~g} / \mathrm{L}$ \\
\hline RM5 & $4.33 \mathrm{~g} / \mathrm{L}$ & $30 \mathrm{~g}$ & $0.10 \mathrm{mg} / \mathrm{L}$ & $0.25 \mathrm{mg} / \mathrm{L}$ & $0.1 \mathrm{~g} / \mathrm{L}$ & $1 \mathrm{~g} / \mathrm{L}$ & $1 \mathrm{~g} / \mathrm{L}$ & $2 \mathrm{~g} / \mathrm{L}$ & $4 \mathrm{~g} / \mathrm{L}$ & $2.66 \mathrm{~g} / \mathrm{L}$ \\
\hline RM6 & $4.33 \mathrm{~g} / \mathrm{L}$ & $30 \mathrm{~g}$ & $0.10 \mathrm{mg} / \mathrm{L}$ & $0.50 \mathrm{mg} / \mathrm{L}$ & $0.1 \mathrm{~g} / \mathrm{L}$ & $1 \mathrm{~g} / \mathrm{L}$ & $1 \mathrm{~g} / \mathrm{L}$ & $2 \mathrm{~g} / \mathrm{L}$ & $4 \mathrm{~g} / \mathrm{L}$ & $2.66 \mathrm{~g} / \mathrm{L}$ \\
\hline RM7 & $4.33 \mathrm{~g} / \mathrm{L}$ & $40 \mathrm{~g}$ & $0.25 \mathrm{mg} / \mathrm{L}$ & 0 & $0.1 \mathrm{~g} / \mathrm{L}$ & $1 \mathrm{~g} / \mathrm{L}$ & $1 \mathrm{~g} / \mathrm{L}$ & $2 \mathrm{~g} / \mathrm{L}$ & $4 \mathrm{~g} / \mathrm{L}$ & $2.66 \mathrm{~g} / \mathrm{L}$ \\
\hline RM8 & $4.33 \mathrm{~g} / \mathrm{L}$ & $40 \mathrm{~g}$ & $0.50 \mathrm{mg} / \mathrm{L}$ & 0 & $0.1 \mathrm{~g} / \mathrm{L}$ & $1 \mathrm{~g} / \mathrm{L}$ & $1 \mathrm{~g} / \mathrm{L}$ & $2 \mathrm{~g} / \mathrm{L}$ & $4 \mathrm{~g} / \mathrm{L}$ & $2.66 \mathrm{~g} / \mathrm{L}$ \\
\hline RM9 & $4.33 \mathrm{~g} / \mathrm{L}$ & $30 \mathrm{~g}$ & $0.25 \mathrm{mg} / \mathrm{L}$ & 0 & $0.1 \mathrm{~g} / \mathrm{L}$ & $1 \mathrm{~g} / \mathrm{L}$ & $1 \mathrm{~g} / \mathrm{L}$ & $2 \mathrm{~g} / \mathrm{L}$ & $4 \mathrm{~g} / \mathrm{L}$ & $2.66 \mathrm{~g} / \mathrm{L}$ \\
\hline RM10 & $4.33 \mathrm{~g} / \mathrm{L}$ & $30 \mathrm{~g}$ & $0.50 \mathrm{mg} / \mathrm{L}$ & 0 & $0.1 \mathrm{~g} / \mathrm{L}$ & $1 \mathrm{~g} / \mathrm{L}$ & $1 \mathrm{~g} / \mathrm{L}$ & $2 \mathrm{~g} / \mathrm{L}$ & $4 \mathrm{~g} / \mathrm{L}$ & $2.66 \mathrm{~g} / \mathrm{L}$ \\
\hline RM11 & $4.33 \mathrm{~g} / \mathrm{L}$ & $40 \mathrm{~g}$ & $0.25 \mathrm{mg} / \mathrm{L}$ & $0.25 \mathrm{mg} / \mathrm{L}$ & $0.1 \mathrm{~g} / \mathrm{L}$ & $1 \mathrm{~g} / \mathrm{L}$ & $1 \mathrm{~g} / \mathrm{L}$ & $2 \mathrm{~g} / \mathrm{L}$ & $4 \mathrm{~g} / \mathrm{L}$ & $2.66 \mathrm{~g} / \mathrm{L}$ \\
\hline RM12 & $4.33 \mathrm{~g} / \mathrm{L}$ & $40 \mathrm{~g}$ & $0.25 \mathrm{mg} / \mathrm{L}$ & $0.50 \mathrm{mg} / \mathrm{L}$ & $0.1 \mathrm{~g} / \mathrm{L}$ & $1 \mathrm{~g} / \mathrm{L}$ & $1 \mathrm{~g} / \mathrm{L}$ & $2 \mathrm{~g} / \mathrm{L}$ & $4 \mathrm{~g} / \mathrm{L}$ & $2.66 \mathrm{~g} / \mathrm{L}$ \\
\hline RM13 & $4.33 \mathrm{~g} / \mathrm{L}$ & $30 \mathrm{~g}$ & $0.25 \mathrm{mg} / \mathrm{L}$ & $0.25 \mathrm{mg} / \mathrm{L}$ & $0.1 \mathrm{~g} / \mathrm{L}$ & $1 \mathrm{~g} / \mathrm{L}$ & $1 \mathrm{~g} / \mathrm{L}$ & $2 \mathrm{~g} / \mathrm{L}$ & $4 \mathrm{~g} / \mathrm{L}$ & $2.66 \mathrm{~g} / \mathrm{L}$ \\
\hline RM14 & $4.33 \mathrm{~g} / \mathrm{L}$ & $30 \mathrm{~g}$ & $0.25 \mathrm{mg} / \mathrm{L}$ & $0.50 \mathrm{mg} / \mathrm{L}$ & $0.1 \mathrm{~g} / \mathrm{L}$ & $1 \mathrm{~g} / \mathrm{L}$ & $1 \mathrm{~g} / \mathrm{L}$ & $2 \mathrm{~g} / \mathrm{L}$ & $4 \mathrm{~g} / \mathrm{L}$ & $2.66 \mathrm{~g} / \mathrm{L}$ \\
\hline RM15 & $4.33 \mathrm{~g} / \mathrm{L}$ & $40 \mathrm{~g}$ & $0.50 \mathrm{mg} / \mathrm{L}$ & $0.25 \mathrm{mg} / \mathrm{L}$ & $0.1 \mathrm{~g} / \mathrm{L}$ & $1 \mathrm{~g} / \mathrm{L}$ & $1 \mathrm{~g} / \mathrm{L}$ & $2 \mathrm{~g} / \mathrm{L}$ & $4 \mathrm{~g} / \mathrm{L}$ & $2.66 \mathrm{~g} / \mathrm{L}$ \\
\hline RM16 & $4.33 \mathrm{~g} / \mathrm{L}$ & $40 \mathrm{~g}$ & $0.50 \mathrm{mg} / \mathrm{L}$ & $0.50 \mathrm{mg} / \mathrm{L}$ & $0.1 \mathrm{~g} / \mathrm{L}$ & $1 \mathrm{~g} / \mathrm{L}$ & $1 \mathrm{~g} / \mathrm{L}$ & $2 \mathrm{~g} / \mathrm{L}$ & $4 \mathrm{~g} / \mathrm{L}$ & $2.66 \mathrm{~g} / \mathrm{L}$ \\
\hline RM17 & $4.33 \mathrm{~g} / \mathrm{L}$ & $30 \mathrm{~g}$ & $0.50 \mathrm{mg} / \mathrm{L}$ & $0.25 \mathrm{mg} / \mathrm{L}$ & $0.1 \mathrm{~g} / \mathrm{L}$ & $1 \mathrm{~g} / \mathrm{L}$ & $1 \mathrm{~g} / \mathrm{L}$ & $2 \mathrm{~g} / \mathrm{L}$ & $4 \mathrm{~g} / \mathrm{L}$ & $2.66 \mathrm{~g} / \mathrm{L}$ \\
\hline RM18 & $4.33 \mathrm{~g} / \mathrm{L}$ & $30 \mathrm{~g}$ & $0.50 \mathrm{mg} / \mathrm{L}$ & $0.50 \mathrm{mg} / \mathrm{L}$ & $0.1 \mathrm{~g} / \mathrm{L}$ & $1 \mathrm{~g} / \mathrm{L}$ & $1 \mathrm{~g} / \mathrm{L}$ & $2 \mathrm{~g} / \mathrm{L}$ & $4 \mathrm{~g} / \mathrm{L}$ & $2.66 \mathrm{~g} / \mathrm{L}$ \\
\hline
\end{tabular}

$\mathrm{MS}=$ Murashige and Skoog medium; 2,4-D = 2,4-dichlorophenoxyacetic acid; BAP = 6-benzylaminopurine.

Table 3. Root induction (1/2 MS) medium.

\begin{tabular}{lc}
\hline $1 / 2$ MS medium & \\
\hline MS salt & $2.165 \mathrm{~g} / \mathrm{L}$ \\
Sucrose & $40.0 \mathrm{~g} / \mathrm{L}$ \\
Myoinositol & $0.05 \mathrm{~g} / \mathrm{L}$ \\
Nicotinic acid & $0.5 \mathrm{~g} / \mathrm{L}$ \\
Pyridoxine $\mathrm{HCl}$ & $0.5 \mathrm{~g} / \mathrm{L}$ \\
Thymine $\mathrm{HCl}$ & $2.0 \mathrm{~g} / \mathrm{L}$ \\
Glycine & $4.0 \mathrm{~g} / \mathrm{L}$ \\
Phytagel & $2.66 \mathrm{~g} / \mathrm{L}$ \\
\hline
\end{tabular}

MS = Murashige and Skoog medium.

A

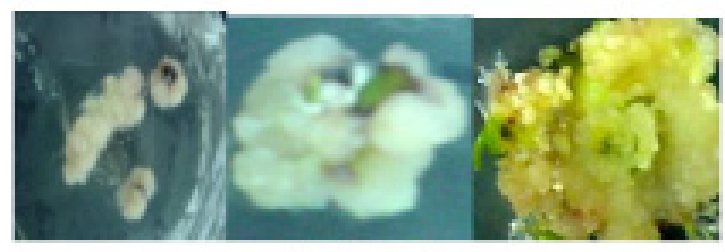

B

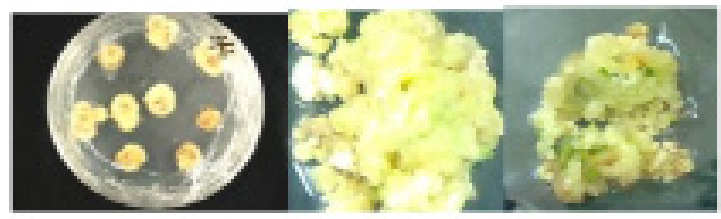

C

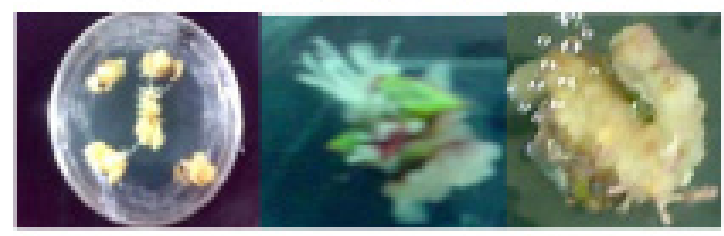

Figure 3. A. Compact and waxy/sticky, less embryogenic callus of S-2006-sp-30. B. Friable and globular embryogenic callus of S-2003-us-359. C. Hairy and waxy callus of S-2003-us-165. 
A

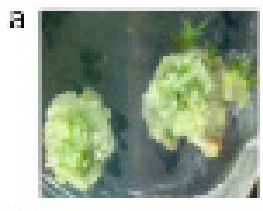

b

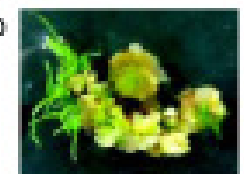

C

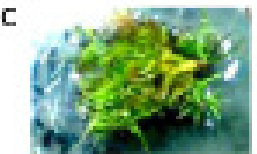

d

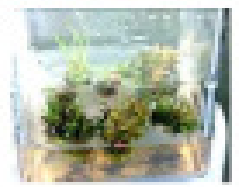

e
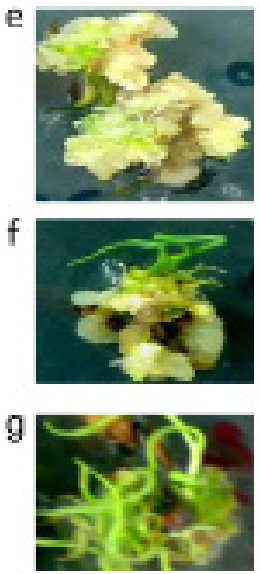

h

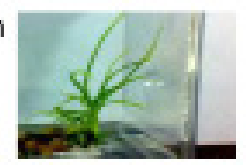

B
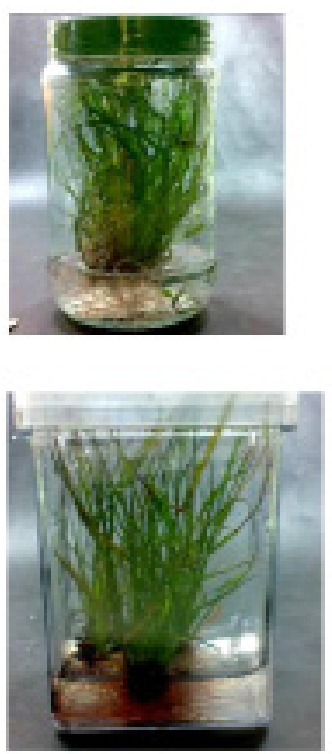

Figure 4. A. Early Shoot formation from calli in genotypes S-2003-us-359 and S-2006-sp-30 (a, b and e, f). Developing shoots at late stage of regeneration on both the genotypes $(\mathbf{c}, \mathbf{d}$ and $\mathbf{g}, \mathbf{h})$. B. Rooting of the regenerated shoots on $1 / 2 \mathrm{MS}$.

In callus induction as well as in regeneration media, Phytagel at a concentration of $2.66 \mathrm{~g} / \mathrm{L}$ was used as a solidifying agent. Medium $\mathrm{pH}$ was adjusted to 5.7-5.8. Media were sterilized in an autoclave at $121^{\circ} \mathrm{C}$ under $15 \mathrm{psi}$ for $20 \mathrm{~min}$ and then the lukewarm medium was poured into sterilized Petri plates, which were sealed with cling film.

\section{Acclimatization of regenerated sugarcane plantlets using a soil mixture of peat and moss}

The regenerated plants were acclimatized under high humidity at $26^{\circ} \mathrm{C}$ and $16-8-\mathrm{h}$ light and dark conditions (Figure 5). Humidity was lowered after one week.

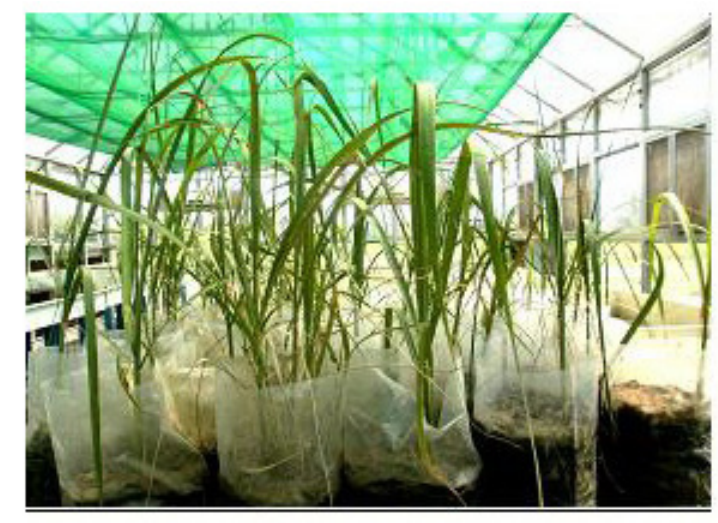

Figure 5. The acclimatized plants being grown in the green house just before transplanting in the field. 


\section{Genetic stability analysis in the regenerants}

The genomic DNA of wild-type and regenerated plants of selected medium combinations was isolated by the protocol described by Palotta et al. (2000). Leaves of plants were cut separately and washed with distilled water, blotted and dried with tissue paper, and then placed in the mortar. Then, liquid nitrogen was added into mortars and plant material was ground into a very fine powder (liquid nitrogen used to freeze all the bio-activity and grinding was done to break the cell wall). Ground leaves $(200 \mathrm{mg})$ were taken in a $1.5-\mathrm{mL}$ reaction tube and treated as follows to get the DNA. Extraction buffer $(700 \mu \mathrm{L})$ (Table 4) was added to the ground tissue. Then, $800 \mu \mathrm{L}$ phenol/chloroform/isoamylalcohol (25:24:1) was added into each reaction tube and mixed thoroughly by inverting the tube until it formed an emulsion and centrifuged for $3 \mathrm{~min}$ at $5000 \mathrm{rpm}$ at $4^{\circ} \mathrm{C}$. The supernatant solution (the top aqueous phase) was then transferred to new reaction tubes and the remaining chloroform phases were discarded. DNA precipitation was achieved by treating the supernatant with 1/10 volume 3 $\mathrm{M}$ sodium acetate at $5.2 \mathrm{pH}$ and 1 volume isopropanol. DNA was pelleted by centrifuging at 13,200 rpm for $15 \mathrm{~min}$. Supernatant was discarded and the pellet was washed with $80 \%$ ethanol, and air dried. After drying, $100 \mu \mathrm{L}$ R-40 (40 $\mu \mathrm{g} / \mathrm{mL}$ RNAse A in 1X TE, pH 8.2) was added in each reaction medium to dissolve the DNA pellet. Concentration, purity and integrity of isolated DNA were checked by nano-drop and gel electrophoresis. DNA was stored at $4^{\circ} \mathrm{C}$ until use.

\begin{tabular}{lc} 
Table 4. Extraction buffer for genomic DNA isolation. \\
\\
\hline Tris-HCl & $100 \mathrm{mM}$ \\
NaCl & $100 \mathrm{mM}$ \\
EDTA & $10 \mathrm{mM}$ \\
Lauryl sarkosyl & $1 \%$ \\
\hline
\end{tabular}

\section{RAPD (PCR) analysis}

Each PCR was carried out in a $25-\mu \mathrm{L}$ reaction volume, containing $7.8 \mu \mathrm{L} \mathrm{d}_{3} \mathrm{H}_{2} \mathrm{O}, 2.5$ $\mu \mathrm{L} 10 \mathrm{X}$ Taq buffer, $2.5 \mu \mathrm{L}$ gelatin, $3 \mu \mathrm{L} \mathrm{MgCl}_{2}, 4 \mu \mathrm{L}$ dNTPs, $0.2 \mu \mathrm{L}$ Taq DNA polymerase, 2 $\mu \mathrm{L}$ primer, and $3 \mu \mathrm{L}$ template DNA. All reactions were conducted in a Mastercycler gradient (Eppendorf, Germany).

\section{PCR (RAPD) amplification profile}

PCR amplification was done by incubating the DNA samples at $94^{\circ} \mathrm{C}$ for $5 \mathrm{~min}$, then 40 cycles comprising denaturation at $94^{\circ} \mathrm{C}$ for $1 \mathrm{~min}$, annealing of primer at $36^{\circ} \mathrm{C}$ for $1 \mathrm{~min}$, and extension at $72^{\circ} \mathrm{C}$ for $2 \mathrm{~min}$. The final extension was carried out at $72^{\circ} \mathrm{C}$ for $10 \mathrm{~min}$. Resolving of PCR product was done by gel electrophoresis using ethidium bromide staining solution. Agarose gel electrophoresis separates macromolecules on the basis of charge, size or other physical properties. PCR products were resolved on $0.8 \%$ agarose in $0.5 \mathrm{X}$ TAE. After electrophoresis, gels were photographed using a gel documentation system, and gel pictures were saved. The list of primers used can be seen in Table 5 . 
Table 5. List of primers with their sequence and annealing temperature.

\begin{tabular}{lllr}
\hline Sr. No. & Primer & Primer sequence $\left(5^{\prime}-3^{\prime}\right)$ & Annealing temperature \\
\hline 1 & GL Decamer B-07 & GGTGACGCAG & $36^{\circ} \mathrm{C}$ \\
2 & GL Decamer B-15 & GGAGGGTGTT & $36^{\circ} \mathrm{C}$ \\
3 & GL Decamer K-15 & CTCCTGCCAA & $36^{\circ} \mathrm{C}$ \\
4 & GL Decamer K-16 & GAGCGTCGAA & $36^{\circ} \mathrm{C}$ \\
5 & GL Decamer L-07 & AGGCGGGAAC & $36^{\circ} \mathrm{C}$ \\
6 & GL Decamer L-12 & GGGCGGTACT & $36^{\circ} \mathrm{C}$ \\
\hline
\end{tabular}

\section{RESULTS}

\section{Callus mass formation and proliferation response of different genotypes}

For the development of an efficient regeneration system, which is indispensable for genetic transformation, three genotypes were selected, viz., S-2003-us-359, S-2006-sp-30 and S-2003-us-165. In this study, the first step was the evaluation of the callus induction response of these genotypes on three different CIM.

CIM had MS basal in common plus 2,4-D at $1 \mathrm{mg} / \mathrm{L}$ (CIM1), $2 \mathrm{mg} / \mathrm{L}$ (CIM2) and 3 $\mathrm{mg} / \mathrm{L}$ (CIM3). These genotypes were cultured and maintained on these three CIM over the 5 weeks to score the callus response. The data were recorded for callus proliferation. Callus proliferation was scored on the basis of a defined scale given in Table 6 .

\begin{tabular}{ll}
\multicolumn{2}{c}{ Table 6. Scale for callus proliferation. } \\
\hline+ & \\
++ & Very low proliferation \\
+++ & Low proliferation \\
++++ & Good proliferation \\
+++++ & Very good proliferation \\
\hline
\end{tabular}

As far as callus mass proliferation over 5 weeks of culturing is concerned, the genotype S-2003-us-359 and S-2006-sp-30 showed better callus formation as compared to S-2003-us-165. Callus mass proliferation was highest in genotype S-2003-us-359 at CIM3 (Figure 6).
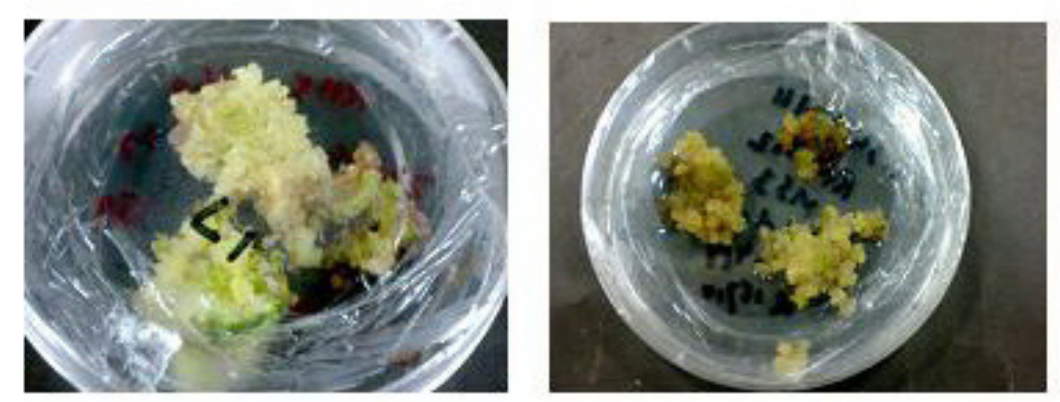

Figure 6. Continuous proliferation of callus on various regeneration media instead of regeneration. 
The analysis of variance (Table 7) reveals the significant variation among the CIM. Variations among genotypes as well as among weeks are also highly significant. Other interactions among the three factors under study are also highly significant.

\begin{tabular}{|c|c|c|c|c|}
\hline Source of variation & Degrees of freedom & Sum of squares & Mean squares & F-value \\
\hline Genotypes & 2 & 111.0027 & 55.5014 & $899.71 * *$ \\
\hline CIM & 2 & 7.1679 & 3.5840 & $58.10^{* *}$ \\
\hline Weeks & 3 & 53.9448 & 17.9816 & $291.49^{* *}$ \\
\hline Genotypes x CIM & 4 & 21.1481 & 5.2870 & $85.71^{* *}$ \\
\hline Genotypes $\mathrm{x}$ weeks & 6 & 22.2987 & 3.7164 & $60.25^{* *}$ \\
\hline CIM x weeks & 6 & 1.4733 & 0.2456 & $3.98 * *$ \\
\hline Genotypes x CIM x weeks & 12 & 3.6176 & 0.3015 & $4.89^{* *}$ \\
\hline Error & 108 & 6.6623 & 0.0617 & \\
\hline Total & 143 & 227.3154 & & \\
\hline
\end{tabular}

**Highly significant $(\mathrm{P}<0.01)$.

If we consider only genotypes, S-2003-us-359 gave the best response followed by genotype S-2006-sp-30, and the genotype S-2003-us-165 gave the poorest response for calli formation (Table 8). Overall means of weeks reveal that the callus mass proliferation rate was stagnant after the 3rd week for all combinations. Two weeks after culturing showed a lower mean value of 1.20 , which relates to less callus mass and at week 3 the mean value increases to 2.32 , showing an increase in callus mass. But at weeks 4 and 5, the mean callus scores were 2.65 and 2.72, respectively, and are similar (Table 9).

Table 8. Overall means of genotypes.
\begin{tabular}{lc} 
& \\
\hline Genotypes & Genotype means \\
\hline S-2003-us-359 & $3.36 \pm 0.19^{\mathrm{A}}$ \\
S-2006-sp-30 & $2.08 \pm 0.11^{\mathrm{B}}$ \\
S-2003-us-165 & $1.22 \pm 0.07^{\mathrm{C}}$ \\
\hline
\end{tabular}

Means sharing similar superscript letters are statistically similar $(\mathrm{P}>0.05)$.

Table 9. Overall means of weeks.

\begin{tabular}{ll}
\hline Weeks & Week means \\
\hline 2nd week & $1.20 \pm 0.07^{\mathrm{C}}$ \\
3rd week & $2.32 \pm 0.22^{\mathrm{B}}$ \\
4th week & $2.65 \pm 0.21^{\mathrm{A}}$ \\
5th week & $2.72 \pm 0.20^{\mathrm{A}}$ \\
\hline
\end{tabular}

Means sharing similar superscript letters are statistically similar $(\mathrm{P}>0.05)$.

By comparing the mean of CIM, a trend was observed (Table 10). Maximum callus formation was observed at CIM3 but slightly less callus formation was found in CIM2. With a mean value of 2.47, CIM3 showed the highest callus induction response followed by CIM2 with a mean value of 2.26. But less callogenesis was observed in CIM1 with a mean value 
of 1.93. In five weeks of data after culturing, genotype S-2003-us-359 showed a mean callus score of 5.00 at CIM3 and 4.00 at CIM2. Genotype S-2003-us-359 at CIM1 and genotype S2006-sp-30 at CIM1 and CIM2 showed a similar response with a mean callus score of 3.00. But genotype S-2006-sp-30 at CIM3 and S-2003-us-165 at CIM1, CIM2 and CIM3 showed a poor response with no statistically significant difference. Genotype S-2006-sp-30 behaved equally at CIM1 and CIM2 but when the 2,4-D concentration was increased to $3 \mathrm{mg} / \mathrm{L}$ (CIM3) the callus formation decreased. In the case of S-2003-us-359, callus formation increased when the concentration of 2,4-D was increased. At CIM3 this genotype showed the best proliferation of calli. Genotype S-2003-us-165 showed a lesser callogenic response in comparison to other genotypes under study at all three levels of 2,4-D (CIM1-CIM3).

Table 10. Overall means of callus induction media (CIM).
\begin{tabular}{ll}
\hline Callus induction media (CIM) & CIM means \\
\hline CIM1 & $1.93 \pm 0.14^{\mathrm{C}}$ \\
CIM2 & $2.26 \pm 0.178^{\mathrm{B}}$ \\
CIM3 & $2.47 \pm 0.22^{\mathrm{A}}$ \\
\hline
\end{tabular}

Means sharing similar superscript letters are statistically similar $(\mathrm{P}>0.05)$.

Table 11 depicts interactions between three factors: genotypes, CIM and weeks. This showed that the genotype S-2003-us-359 at weeks 3, 4 and 5 at CIM3 behaved equally well, with the highest mean value of 5.00 and this genotype produced the highest callus mass for these weeks at CIM3. This genotype scored a mean value of 3.67, 4.00 and 4.00 for the $3 \mathrm{rd}$, 4th and 5th weeks, respectively, at CIM 2. The response of genotype S-2003-us-359 at CIM1 and genotype S-2006-sp-30 at CIM1 and CIM2 for the 4th and 5th weeks was observed to be the same with a mean value of 3.00. But the response of S-2006-sp-30 decreased to a mean value of 2.00 at CIM3 for the 3rd, 4th and 5th weeks. The behavior of S-2006-sp-30 for week 2 for all the three CIM was the same with a mean value of 1.00 . A very poor response was observed in genotype S-2003-us-165 for the 2nd and 3rd weeks at CIM1, CIM2 with a mean score of 0.92 and 0.84 , respectively, which are statistically similar values.

\begin{tabular}{|c|c|c|c|c|}
\hline Genotypes & Weeks & CIM1 & CIM2 & CIM3 \\
\hline \multirow[t]{4}{*}{ S-2003-us-359 } & 2nd & $1.00 \pm 0.00^{\mathrm{fg}}$ & $1.67 \pm 0.00^{\text {de }}$ & $2.00 \pm 0.00^{\mathrm{d}}$ \\
\hline & $3 \mathrm{rd}$ & $3.00 \pm 0.00^{\circ}$ & $3.67 \pm 0.00^{b}$ & $5.00 \pm 0.00^{\mathrm{a}}$ \\
\hline & 4th & $3.00 \pm 0.00^{\circ}$ & $4.00 \pm 0.00^{\mathrm{b}}$ & $5.00 \pm 0.00^{\mathrm{a}}$ \\
\hline & 5th & $3.00 \pm 0.00^{c}$ & $4.00 \pm 0.00^{\mathrm{b}}$ & $5.00 \pm 0.00^{\mathrm{a}}$ \\
\hline \multirow{4}{*}{ S-2006-sp-30 } & 2nd & $1.00 \pm 0.00^{\mathrm{fg}}$ & $1.00 \pm 0.00^{\mathrm{fg}}$ & $1.00 \pm 0.00^{\mathrm{fg}}$ \\
\hline & $3 \mathrm{rd}$ & $2.00 \pm 0.00^{\mathrm{d}}$ & $2.00 \pm 0.00^{\mathrm{d}}$ & $2.00 \pm 0.00^{\mathrm{d}}$ \\
\hline & 4th & $3.00 \pm 0.00^{c}$ & $3.00 \pm 0.00^{c}$ & $2.00 \pm 0.00^{\mathrm{d}}$ \\
\hline & 5th & $3.00 \pm 0.00^{c}$ & $3.00 \pm 0.00^{c}$ & $2.00 \pm 0.00^{\mathrm{d}}$ \\
\hline \multirow{4}{*}{ S-2003-us-165 } & 2 nd & $0.92 \pm 0.16^{\mathrm{g}}$ & $0.84 \pm 0.10^{\mathrm{g}}$ & $1.34 \pm 0.30^{\text {ef }}$ \\
\hline & $3 \mathrm{rd}$ & $0.92 \pm 0.16^{\mathrm{g}}$ & $1.00 \pm 0.14^{\mathrm{fg}}$ & $1.34 \pm 0.30^{\mathrm{ef}}$ \\
\hline & 4th & $1.00 \pm 0.23^{\text {fg }}$ & $1.34 \pm 0.30^{\text {ef }}$ & $1.50 \pm 0.17^{\mathrm{e}}$ \\
\hline & 5 th & $1.34 \pm 0.23^{\mathrm{ef}}$ & $1.67 \pm 0.19^{\mathrm{de}}$ & $1.50 \pm 0.17^{\mathrm{e}}$ \\
\hline
\end{tabular}

Statistical analysis (Duncan multiple range test) for callus induction and proliferation in sugarcane genotypes at different callus induction media (CIM) and time (in weeks). Means sharing similar superscript letters in a row or in a column are statistically non-significant $(\mathrm{P}>0.05)$. 


\section{Regeneration response in selected genotypes}

After evaluating the callogenic response of these genotypes, two genotypes, S2003-us-359 and S-2006-sp-30, were selected to check the regeneration response. In order to obtain enhanced regeneration in these genotypes, different regeneration media were used. These media differed in 2,4-D, BAP, and sucrose levels. The regeneration medium (RM) used in this experiment was a modified MS medium supplemented with different levels of 2,4-D $(0.1,0.25$ and $0.5 \mathrm{mg} / \mathrm{L}), \mathrm{BAP}(0,0.25$ and $0.5 \mathrm{mg} / \mathrm{L})$ and sucrose $(30$ and $40 \mathrm{~g} / \mathrm{L})$ (Figure 7$)$.
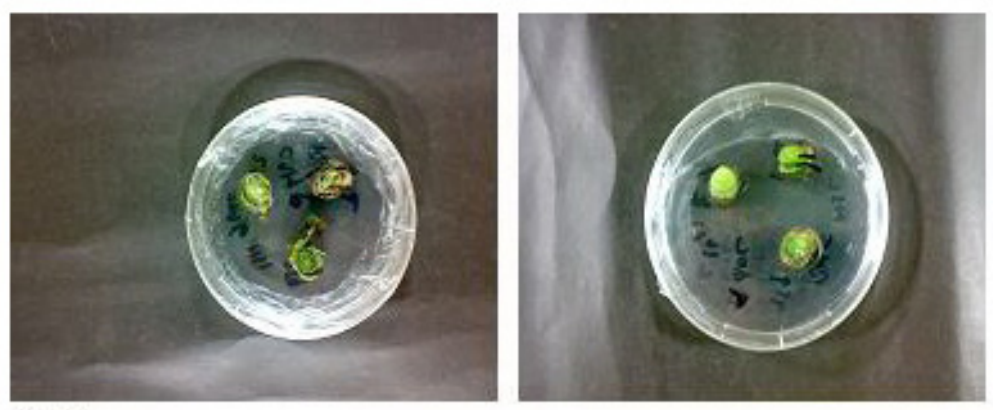

Figure 7. Different regeneration media showing no response to regeneration to particular callus age.

Among these combinations RM3 proved to be the best for both genotypes. Analysis of variance reveals that variation among the genotypes, regeneration media, callus age (in days), and their interactions proved to be highly significant (Table 12).

Table 12. Analysis of variance (ANOVA) for plantlet regeneration in sugarcane genotypes.

\begin{tabular}{|c|c|c|c|c|}
\hline Source of variation & Degrees of freedom & Sum of squares & Mean squares & F-value \\
\hline Genotypes & 1 & 1534.43 & 1534.43 & $271.16 * *$ \\
\hline CIM & 2 & 515.84 & 257.92 & $45.58 * *$ \\
\hline Days & 3 & 2260.52 & 753.51 & $133.16 * *$ \\
\hline RM & 17 & 15905.98 & 935.65 & $165.34 * *$ \\
\hline Genotypes x CIM & 2 & 553.35 & 276.67 & $48.89 * *$ \\
\hline Genotypes $\mathrm{x}$ days & 3 & 897.94 & 299.31 & $52.89 * *$ \\
\hline Genotypes x RM & 17 & 7923.10 & 466.06 & $82.36^{* *}$ \\
\hline CIM $\mathrm{x}$ days & 6 & 795.46 & 132.58 & $23.43 * *$ \\
\hline CIM x RM & 34 & 4589.57 & 134.99 & $23.85 * *$ \\
\hline Days x RM & 51 & 12448.62 & 244.09 & $43.13 * *$ \\
\hline Genotypes $\mathrm{x}$ CIM $\mathrm{x}$ days & 6 & 641.34 & 106.89 & $18.89^{* *}$ \\
\hline Genotypes x CIM x RM & 34 & 5785.64 & 170.17 & $30.07 * *$ \\
\hline Genotypes $\mathrm{x}$ days $\mathrm{x}$ RM & 51 & 8743.82 & 171.45 & $30.30 * *$ \\
\hline CIM $x$ days $x$ RM & 102 & 10183.17 & 99.83 & $17.64 * *$ \\
\hline Genotypes $\mathrm{x}$ CIM $\mathrm{x}$ days $\mathrm{x}$ RM & 102 & 10621.72 & 104.13 & $18.40^{* *}$ \\
\hline Error & 864 & 4889.21 & 5.66 & \\
\hline Total & 1295 & 88289.72 & & \\
\hline
\end{tabular}

$\mathrm{CIM}=$ callus induction media; $\mathrm{RM}=$ regeneration media. $* *$ Highly significant $(\mathrm{P}<0.01)$.

Twenty-one-day-old embryogenic calli of S-2003-us-359 on CIM3 proved to be the best for regeneration on RM3 with a mean value of 134.44 shoots per explants (Table 13; Figure $8 \mathrm{~B}$ ) and was selected as the medium combination used in the genetic transformation experiment as tissue culture media. This medium combination was followed by 28 -day-old calli 
of this genotype, produced from CIM2 and CIM3 media, which showed excellent regeneration on the RM3 media with a mean value of 44.44 and 44.33 shoots per explant respectively (Table 13; Figure 8C).

\begin{tabular}{|c|c|c|c|c|c|c|c|c|c|c|c|}
\hline \multirow[t]{2}{*}{$\overline{\mathrm{G}}$} & \multirow[t]{2}{*}{ Days } & \multirow[t]{2}{*}{ CIM } & \multicolumn{9}{|c|}{ Regeneration media (RM) } \\
\hline & & & RM1 & RM2 & RM3 & RM4 & RM5 & RM6 & RM7 & RM8 & RM9 \\
\hline \multirow[t]{12}{*}{ S-2003-us-359 } & \multirow[t]{3}{*}{15} & CIM1 & $0.45^{\vee-z}$ & $0.230^{x y z}$ & $0.781^{\mathrm{u}-\mathrm{z}}$ & $0.01^{z}$ & $0.230^{x y z}$ & $4.001^{1-z}$ & $0.01^{z}$ & $0.01^{z}$ & $0.01^{2}$ \\
\hline & & CIM2 & $0.673^{\mathrm{u}-\mathrm{z}}$ & $0.01^{2}$ & $0.01^{2}$ & $0.01^{2}$ & $0.01^{2}$ & $1.894^{p-2}$ & $0.01^{z}$ & $0.01^{2}$ & $0.01^{2}$ \\
\hline & & CIM3 & $1.669^{\mathrm{q}-\mathrm{z}}$ & $0.671^{\mathrm{u}-\mathrm{z}}$ & $3.001^{0-z}$ & $0.120^{y-z}$ & $4.223^{\mathrm{k}-\mathrm{z}}$ & $0.0^{1 z}$ & $0.01^{z}$ & $0.01^{z}$ & $0.01^{2}$ \\
\hline & \multirow[t]{3}{*}{21} & CIM1 & $16.667^{\mathrm{fg}}$ & $0.782^{\mathrm{u}-\mathrm{z}}$ & $17.557^{\mathrm{fg}}$ & $2.557^{0-2}$ & $3.333^{n-2}$ & $2.225^{\mathrm{p}-\mathrm{z}}$ & $0.01^{z}$ & $0.01^{2}$ & $0.01^{2}$ \\
\hline & & CIM2 & $3.001^{\mathrm{o}-\mathrm{z}}$ & $2.448^{0-z}$ & $28.111^{\text {cd }}$ & $15.778^{\mathrm{fg}}$ & $5.667^{\mathrm{i}-2}$ & $2.556^{0-z}$ & $0.01^{2}$ & $0.01^{z}$ & $0.01^{\mathrm{z}}$ \\
\hline & & CIM3 & $14.889^{\mathrm{gh}}$ & $23.111^{\mathrm{e}}$ & $134.444^{\mathrm{a}}$ & $5.781^{1-z}$ & $8.891^{\mathrm{i}-\mathrm{n}}$ & $6.222^{i-v}$ & $0.01^{z}$ & $0.01^{z}$ & $0.01^{z}$ \\
\hline & \multirow[t]{3}{*}{28} & CIM1 & $24.44^{\mathrm{de}}$ & $9.333^{-m}$ & $1.895^{p-z}$ & $1.338^{\mathrm{r}-\mathrm{z}}$ & $32.111^{\mathrm{c}}$ & $1.339^{r-2}$ & $0.01^{2}$ & $0.01^{z}$ & $0.01^{\mathrm{z}}$ \\
\hline & & CIM2 & $2.228^{p-z}$ & $8.112^{\mathrm{i}-\mathrm{o}}$ & $44.44^{\mathrm{b}}$ & $6.89^{\mathrm{i-r}}$ & $7.445^{\mathrm{i}-\mathrm{q}}$ & $11.00^{\mathrm{hi}}$ & $0.01^{z}$ & $0.01^{z}$ & $0.01^{z}$ \\
\hline & & CIM3 & $9.667^{\mathrm{jik}}$ & $5.665^{\mathrm{i}-2}$ & $44.333^{b}$ & $4.558^{\mathrm{j}-\mathrm{z}}$ & $23.778^{\mathrm{de}}$ & $15.22^{\text {fgh }}$ & $0.01^{2}$ & $0.01^{z}$ & $0.01^{z}$ \\
\hline & \multirow[t]{3}{*}{35} & CIM1 & $1.889^{\mathrm{p}-\mathrm{z}}$ & $3.781^{\mathrm{i}-\mathrm{m}}$ & $10.111^{i-\mathrm{j}}$ & $3.337^{n-2}$ & $3.893^{1-2}$ & $5.224^{j-z}$ & $0.01^{z}$ & $0.01^{2}$ & $0.01^{z}$ \\
\hline & & CIM2 & $0.230^{x y z}$ & $5.446^{\mathrm{i}-\mathrm{z}}$ & $6.113^{\mathrm{i}-\mathrm{w}}$ & $1.114^{\mathrm{r}-\mathrm{z}}$ & $2.227^{p-z}$ & $2.559^{0-2}$ & $0.01^{z}$ & $0.01^{2}$ & $0.01^{2}$ \\
\hline & & CIM3 & $0.01^{2}$ & $4.336^{k-2}$ & $7.557^{\mathrm{i}-\mathrm{p}}$ & $20.00^{\text {ef }}$ & $7.556^{\mathrm{i}-\mathrm{p}}$ & $0.120^{y z}$ & $0.01^{z}$ & $0.01^{2}$ & $0.01^{2}$ \\
\hline \multirow{12}{*}{ S-2006-sp-30 } & \multirow{3}{*}{15} & CIM1 & $0.01^{z}$ & $0.01^{z}$ & $0.01^{z}$ & $0.01^{2}$ & $0.01^{z}$ & $0.01^{2}$ & $0.01^{2}$ & $0.01^{2}$ & $0.01^{2}$ \\
\hline & & CIM2 & $0.01^{2}$ & $0.01^{2}$ & $0.01^{2}$ & $0.01^{2}$ & $0.01^{z}$ & $0.01^{2}$ & $0.01^{z}$ & $0.01^{2}$ & $0.01^{2}$ \\
\hline & & CIM3 & $0.01^{2}$ & $0.01^{2}$ & $0.01^{2}$ & $0.01^{2}$ & $0.01^{2}$ & $0.01^{2}$ & $0.01^{2}$ & $0.01^{2}$ & $0.01^{2}$ \\
\hline & \multirow[t]{3}{*}{21} & CIM1 & $5.22^{\mathrm{j}-\mathrm{z}}$ & $2.33^{p-z}$ & $6.778^{i-s}$ & $0.01^{2}$ & $0.01^{z}$ & $0.01^{2}$ & $4.111^{\mathrm{k}-\mathrm{z}}$ & $0.01^{2}$ & $0.01^{2}$ \\
\hline & & CIM2 & $3.445^{\mathrm{n}-\mathrm{z}}$ & $3.445^{n-2}$ & $5.89^{-i y}$ & $0.01^{2}$ & $0.01^{2}$ & $0.01^{2}$ & $3.001^{0-2}$ & $0.01^{2}$ & $0.01^{2}$ \\
\hline & & CIM3 & $5.556^{\mathrm{i}-\mathrm{z}}$ & $6.667^{\mathrm{i}-\mathrm{t}}$ & $6.668^{i-t}$ & $0.01^{2}$ & $0.01^{z}$ & $0.01^{2}$ & $4.001^{1-z}$ & $0.01^{2}$ & $0.01^{2}$ \\
\hline & \multirow[t]{3}{*}{28} & CIM1 & $1.223^{\mathrm{r}-\mathrm{z}}$ & $7.333^{\mathrm{i}-\mathrm{q}}$ & $16.44^{\mathrm{fg}}$ & $9.446^{\mathrm{i}-1}$ & $1.334^{r-2}$ & $1.003^{s-2}$ & $0.01^{z}$ & $0.01^{2}$ & $0.01^{2}$ \\
\hline & & CIM2 & $2.001^{\mathrm{p}-\mathrm{z}}$ & $2.891^{0-z}$ & $4.778^{\mathrm{j}-z}$ & $3.445^{n-2}$ & $1.781^{\mathrm{p}-\mathrm{z}}$ & $0.01^{z}$ & $0.01^{z}$ & $0.01^{z}$ & $0.01^{z}$ \\
\hline & & CIM3 & $1.003^{s-2}$ & $6.335^{\mathrm{i}-\mathrm{u}}$ & $5.889^{\mathrm{i}-\mathrm{y}}$ & $5^{\mathrm{j}-2}$ & $1.224^{r-2}$ & $0.01^{2}$ & $0.01^{2}$ & $0.01^{2}$ & $0.01^{z}$ \\
\hline & \multirow[t]{3}{*}{35} & CIM1 & $1.668^{\mathrm{q}-\mathrm{n}}$ & $3.444^{n-2}$ & $6^{\mathrm{i}-\mathrm{x}}$ & $0.01^{z}$ & $0.01^{\mathrm{z}}$ & $0.01^{z}$ & $0.01^{z}$ & $0.01^{z}$ & $0.01^{z}$ \\
\hline & & CIM2 & $0.01^{2}$ & $1.337^{\mathrm{r}-\mathrm{z}}$ & $1.89^{p-z}$ & $0.01^{z}$ & $0.01^{2}$ & $0.01^{2}$ & $0.01^{z}$ & $0.01^{z}$ & $0.01^{z}$ \\
\hline & & CIM3 & $0.01^{z}$ & $3.223^{\mathrm{n}-\mathrm{z}}$ & $3.223^{\mathrm{n}-\mathrm{z}}$ & $0.01^{2}$ & $0.01^{2}$ & $0.01^{z}$ & $0.01^{2}$ & $0.01^{z}$ & $0.01^{z}$ \\
\hline \multirow[t]{2}{*}{ G } & \multirow[t]{2}{*}{ Days } & \multirow[t]{2}{*}{ CIM } & & & & Regenerati & on media $(\mathrm{F}$ & $\mathrm{RM})$ & & & \\
\hline & & & RM10 & RM11 & RM12 & RM13 & RM14 & RM15 & RM16 & RM17 & RM 18 \\
\hline S-2003-us-359 & 15 & CIM1 & $0.01^{z}$ & $0.230^{x y z}$ & $0.01^{z}$ & $0.01^{z}$ & $0.01^{z}$ & $0.01^{2}$ & $0.01^{z}$ & $0.01^{z}$ & $0.01^{2}$ \\
\hline & & CIM2 & $0.01^{z}$ & $0.01^{2}$ & $0.01^{2}$ & $0.01^{2}$ & $0.01^{2}$ & $0.01^{2}$ & $0.01^{2}$ & $0.01^{2}$ & $0.01^{2}$ \\
\hline & & CIM3 & $0.01^{z}$ & $0.01^{z}$ & $0.01^{2}$ & $0.01^{z}$ & $0.01^{z}$ & $0.01^{z}$ & $0.01^{z}$ & $0.01^{z}$ & $0.01^{2}$ \\
\hline & 21 & CIM1 & $0.01^{2}$ & $0.12^{y z}$ & $0.01^{2}$ & $0.34^{\mathrm{w}-\mathrm{z}}$ & $0.01^{2}$ & $0.01^{2}$ & $0.01^{z}$ & $0.01^{2}$ & $0.01^{2}$ \\
\hline & & CIM2 & $0.01^{z}$ & $0.450^{\mathrm{v}-\mathrm{z}}$ & $0.01^{2}$ & $0.12^{y z}$ & $0.12^{y z}$ & $0.01^{z}$ & $0.01^{z}$ & $0.01^{z}$ & $0.01^{2}$ \\
\hline & & CIM3 & $0.01^{2}$ & $0.89^{t-2}$ & $0.12^{y z}$ & $0.12^{y z}$ & $0.01^{z}$ & $0.01^{2}$ & $0.01^{2}$ & $0.01^{z}$ & $0.01^{z}$ \\
\hline & 28 & CIM1 & $0.01^{2}$ & $0.01^{2}$ & $0.01^{z}$ & $0.01^{2}$ & $0.01^{2}$ & $0.01^{2}$ & $0.01^{z}$ & $0.01^{2}$ & $0.01^{2}$ \\
\hline & & CIM2 & $0.01^{2}$ & $0.01^{2}$ & $0.01^{2}$ & $0.01^{2}$ & $0.01^{2}$ & $0.01^{z}$ & $0.01^{z}$ & $0.01^{z}$ & $0.01^{z}$ \\
\hline & & CIM3 & $0.01^{2}$ & $0.01^{2}$ & $0.01^{z}$ & $0.01^{2}$ & $0.01^{2}$ & $0.01^{2}$ & $0.01^{z}$ & $0.01^{2}$ & $0.01^{2}$ \\
\hline & 35 & CIM1 & $0.01^{2}$ & $0.01^{2}$ & $0.01^{2}$ & $0.01^{2}$ & $0.01^{2}$ & $0.01^{2}$ & $0.01^{z}$ & $0.01^{z}$ & $0.01^{2}$ \\
\hline & & CIM2 & $0.01^{z}$ & $0.01^{z}$ & $0.01^{2}$ & $0.01^{z}$ & $0.01^{2}$ & $0.01^{2}$ & $0.01^{z}$ & $0.01^{z}$ & $0.01^{2}$ \\
\hline & & CIM3 & $0.01^{2}$ & $0.01^{2}$ & $0.01^{2}$ & $0.01^{2}$ & $0.01^{2}$ & $0.01^{2}$ & $0.01^{z}$ & $0.01^{z}$ & $0.01^{2}$ \\
\hline S-2006-sp-30 & 15 & CIM1 & $0.01^{z}$ & $0.01^{2}$ & $0.01^{2}$ & $0.01^{z}$ & $0.01^{2}$ & $0.01^{z}$ & $0.01^{z}$ & $0.01^{z}$ & $0.01^{z}$ \\
\hline & & CIM2 & $0.01^{2}$ & $0.01^{2}$ & $0.01^{2}$ & $0.01^{2}$ & $0.01^{2}$ & $0.01^{2}$ & $0.01^{z}$ & $0.01^{z}$ & $0.01^{2}$ \\
\hline & & CIM3 & $0.01^{2}$ & $0.01^{2}$ & $0.01^{2}$ & $0.01^{2}$ & $0.01^{2}$ & $0.01^{\mathrm{z}}$ & $0.01^{2}$ & $0.01^{2}$ & $0.01^{z}$ \\
\hline & 21 & CIM1 & $0.01^{z}$ & $0.01^{z}$ & $0.01^{2}$ & $0.01^{z}$ & $0.01^{z}$ & $0.01^{2}$ & $0.01^{2}$ & $0.01^{2}$ & $0.01^{z}$ \\
\hline & & CIM2 & $0.01^{2}$ & $0.01^{2}$ & $0.01^{2}$ & $0.01^{2}$ & $0.01^{2}$ & $0.01^{z}$ & $0.01^{z}$ & $0.01 \mathrm{z}$ & $0.01^{z}$ \\
\hline & & CIM3 & $0.01^{z}$ & $0.01^{z}$ & $0.01^{z}$ & $0.01^{z}$ & $0.01^{z}$ & $0.01^{2}$ & $0.01^{2}$ & $0.01^{z}$ & $0.01^{z}$ \\
\hline & 28 & CIM1 & $0.01^{2}$ & $1.115^{\mathrm{r}-\mathrm{z}}$ & $0.01^{z}$ & $2.778^{0-z}$ & $1.334^{r-2}$ & $0.01^{2}$ & $0.01^{z}$ & $0.01^{2}$ & $0.01^{z}$ \\
\hline & & CIM2 & $1.335^{\mathrm{r}-\mathrm{z}}$ & $2.004^{p-z}$ & $0.01^{z}$ & $0.673^{\mathrm{u}-\mathrm{z}}$ & $0.45^{\mathrm{v}-\mathrm{z}}$ & $0.01^{z}$ & $0.01^{z}$ & $0.01^{z}$ & $0.01^{2}$ \\
\hline & & CIM3 & $1.005^{5-2}$ & $2.001^{\mathrm{p}-\mathrm{z}}$ & $0.01^{2}$ & $1.447^{\mathrm{r}-\mathrm{z}}$ & $1.225^{\mathrm{r}-\mathrm{z}}$ & $0.01^{2}$ & $0.01^{z}$ & $0.01^{z}$ & $0.01^{2}$ \\
\hline & 35 & CIM1 & $0.01^{z}$ & $0.01^{2}$ & $0.01^{z}$ & $2.111^{\mathrm{p}-\mathrm{z}}$ & $1.445^{\mathrm{r}-\mathrm{z}}$ & $0.01^{z}$ & $0.01^{z}$ & $1.891^{\mathrm{p}-\mathrm{z}}$ & $2.667^{0-2}$ \\
\hline & & CIM2 & $0.01^{2}$ & $0.01^{2}$ & $0.01^{2}$ & $1.781^{p-z}$ & $1.89^{\mathrm{p}-\mathrm{z}}$ & $0.01^{2}$ & $0.01^{z}$ & $2.003^{\mathrm{p}-\mathrm{z}}$ & $0.01^{2}$ \\
\hline & & CIM3 & $0.01^{z}$ & $0.01^{z}$ & $0.01^{z}$ & $1.115^{\mathrm{r}-\mathrm{z}}$ & $2.222^{p-z}$ & $0.01^{z}$ & $0.01^{z}$ & $2.001^{p-z}$ & $0.01^{2}$ \\
\hline
\end{tabular}

Statistical analysis (Duncan multiple range test) for regeneration in sugarcane genotypes. Means sharing similar superscript letters in a row or in a column are statistically non-significant $(\mathrm{P}>0.05) . \mathrm{G}=$ genotypes; $\mathrm{CIM}=$ callus induction media. 

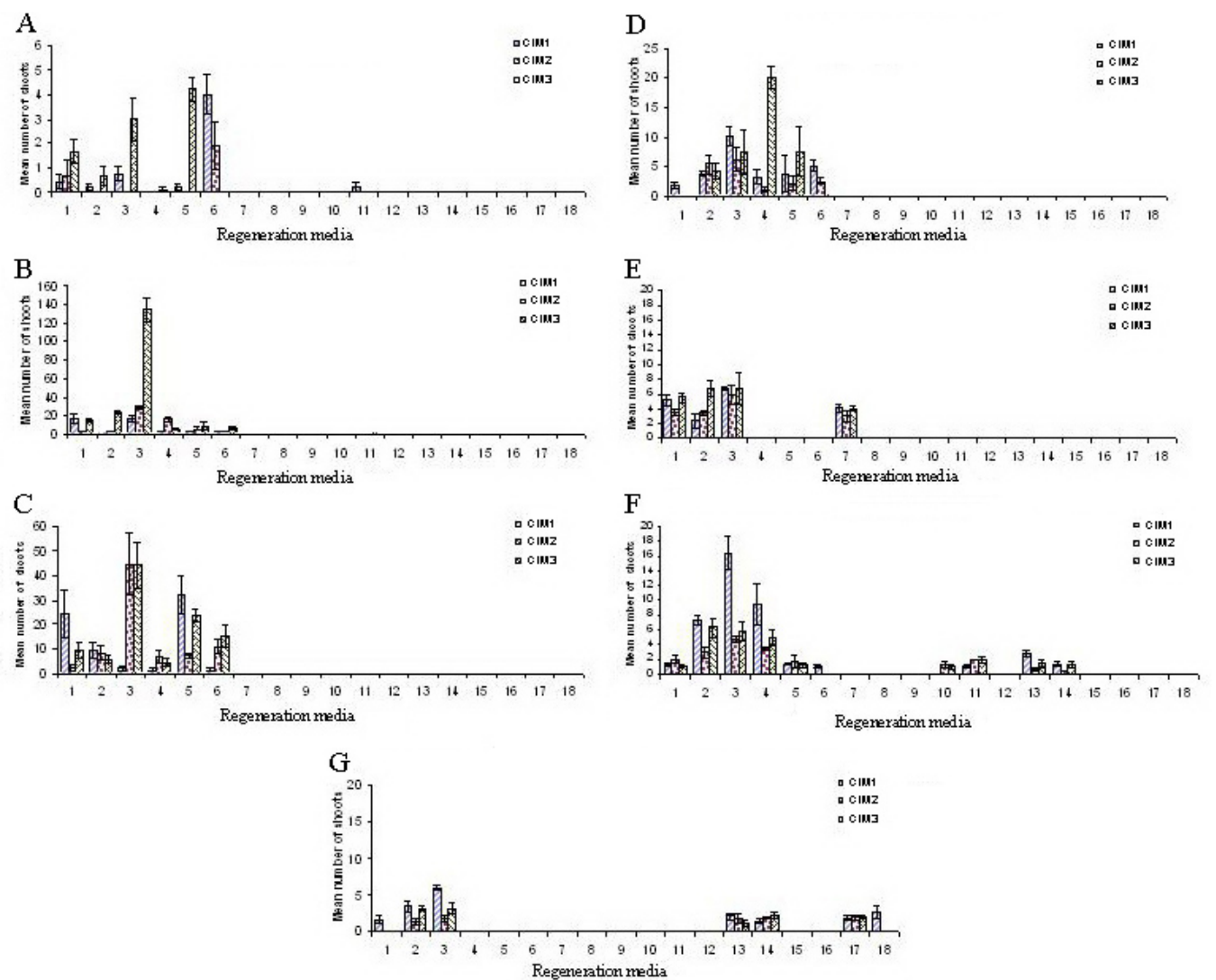

Figure 8. A. Behavior of 15-day-old calli of genotype S-2003-us-359 on 18 different regeneration media. B. Behavior of 21-day-old calli of genotype S-2003-us-359 on 18 different regeneration media. C. Behavior of 28-day-old calli of genotype S-2003-us-359 on 18 different regeneration media. D. Behavior of 35-day-old calli of genotype S-2003-us-359 on 18 different regeneration media. E. Behavior of 21-day-old calli of genotype S-2006sp-30 on 18 different regeneration media. F. Behavior of 28-day-old-calli of genotype S-2006-sp-30 on 18 different regeneration media. G. Behavior of 35-day-old calli of genotype S-2006-sp-30 on 18 different regeneration media. $\mathrm{CIM}=$ callus induction media .

In the case of S-2006-sp-30, the best regeneration response was again observed for RM3 medium. Twenty-eight-day-old callus at CIM1 medium produced on an average of 16.44 shoots per explant (Table 13; Figure 8C). This was followed by RM4 medium with a mean value of 9.446 shoots per explant. These results showed that regeneration media (RM3) was the most efficient although the origin of calli varied in both genotypes.

There was no response to regeneration in the case of 28- and 35-day-old calli of S2003-us-359 from CIM1, CIM2 and CIM3 on regeneration media RM7 to RM18 (Figure 8C and D). Calli mass was proliferated continuously on all these media, as shown in Figure 6.

As for as the 15-day-old calli of S-2003-us-359 from CIM1, CIM2 and CIM3 media, there was no regeneration observed on regeneration media RM7 to RM18 except on RM11, on which 15-day-old calli of this genotype from CIM1 responded with a mean value of 0.230 shoots per explant (Figure 8A). In this case, calli mass proliferation was not observed but a 
low mass of calli or no callus formation was observed, and explants on these regeneration media first became green and then black. On RM11 some shoots emerged from the sides of little callus mass, which was not the case for other non-responsive media.

In the case of S-2006-sp-30, no regeneration was observed from 15-day-old calli and, on regeneration, the calli tended to become black. For 21-day-old calli, no regeneration was observed on RM4 to RM6 and RM8 to RM18 (Figure 8E). For 28-day-old calli, no regeneration response was observed on RM6 to RM9 and RM15 to RM18 (Figure 8F) and in the case of 35-day-old calli, no regeneration was observed on RM4 to RM11 (Figure 8G). For this genotype, little regeneration response was observed on RM14 from 28-day-old calli of CIM2 with a mean value of 0.45 shoots per explant.

\section{Confirmation of genetic stability}

The genetic stability was determined using RAPD primers given in Table 5 . The results showed the same pattern of amplification for RAPD primers used upon DNA extracted from wild (non-regenerated) and regenerated samples (Figure 9A and B). These regenerated samples were the plants that were grown on selected medium combinations. This means that the optimized tissue culture medium combinations did not bring about any genetic change in the regenerants and the medium combination is fit for any transformation experiment.

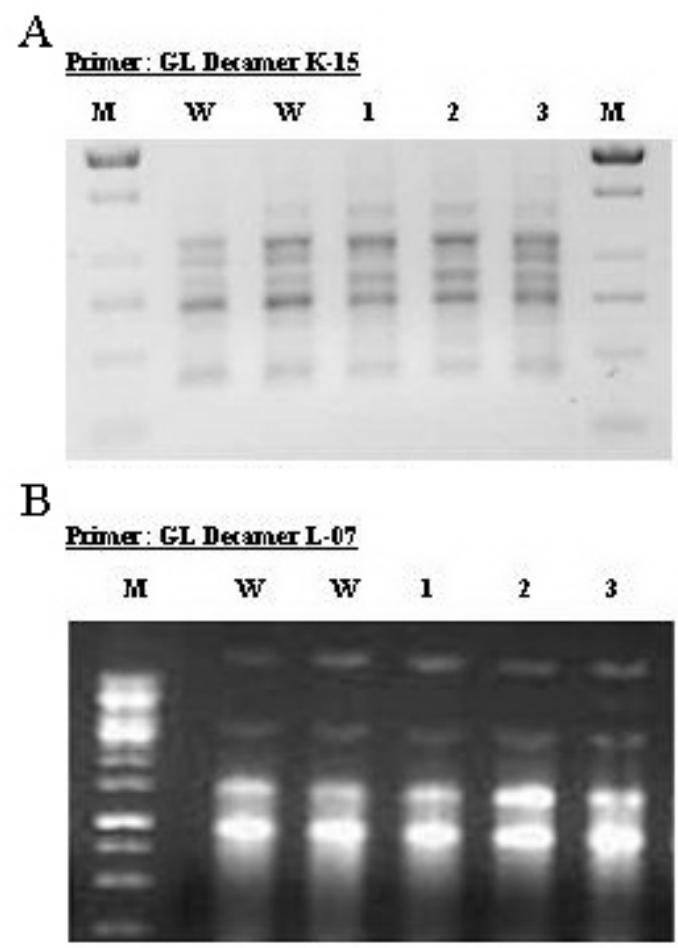

Figure 9. A. RAPD (PCR) analysis of sugarcane genotypes with primer GL Decamer K-15. Lanes $M=1-\mathrm{kb}$ ladder; lanes $W=$ wild-type samples; lanes 1, 2, 3 = regenerated samples. B. RAPD (PCR) analysis of sugarcane genotypes with primer GL Decamer L-07. Lane $M=1$-kb ladder; lanes $W=$ wild-type samples; lanes 1, 2, 3 = regenerated samples. 


\section{DISCUSSION}

Lack of an effective, efficient and reproducible regeneration system to generate transformed plants at a satisfactory rate is still the key factor seriously restricting the enhancement of crops through genetic transformation (Popelka and Altpeter, 2003). Therefore, the first part of the study addresses the establishment of an efficient in vitro regeneration system in selected sugarcane genotypes. Tissue culture is a powerful tool for studying and solving basic and applied problems in plant biotechnology. A tissue culture system provides considerable quantities of highly regenerable target tissue. Effectual exploitation of biotechnological approaches, such as somaclonal variant isolation, protoplast fusion and genetic transformation, rely on an efficient regeneration system. Basically, every part of the sugarcane plant has competency for callus production (Liu, 1981) although only immature leaves (Irvine and Benda, 1987) and the inflorescence (Liu, 1981) are able to produce morphogenic callus to any significant level. Regeneration of plants can be achieved directly (adventitiously) from the explant (Geijskes et al., 2003) or indirectly through the callus derived from the explants (Heinz and Mee, 1969). From callus culture, regeneration of sugarcane occurs either by organogenesis (Barba and Nickell, 1969) or by somatic embryogenesis (Ho and Vasil, 1983) upon prolonged callus culture.

For this study, three genotypes of sugarcane were used, viz., S-2003-us-359, S2006-sp-30 and S-2003-us-165, and young immature leaves were used as an explant to induce callus. Brisibe et al. (1994) also suggested immature leaves of sugarcane as an excellent plant source for callus production. Swift callus formation has been obtained from young leaves. We used three callus induction media for callus production and these media have MS salt in common but varying levels of 2,4-D (1-3 mg/L). Here growth regulator 2,4-D was used alone for callus mass proliferation. Three different levels of 2,4-D were studied: 1,2 and $3 \mathrm{mg} / \mathrm{L}$. The highest callus mass production was obtained at $3 \mathrm{mg} / \mathrm{L}$ 2,4-D in genotype S-2003-us-359 with a mean value of 5.00 and genotype S-2006-sp-30 showed good callus formation response at 1 and $2 \mathrm{mg} / \mathrm{L}$ with a mean score of 3.00 as compared to the $3 \mathrm{mg} / \mathrm{L}$ 2,4-D level. But genotype S-2003-us-165 showed more response for callus production at $3 \mathrm{mg} / \mathrm{L} 2,4-\mathrm{D}$ by scoring 1.5 mean values above the other two levels. For callus formation 2,4-D is found to be the most effective. Different scientists have tested different concentrations of 2,4-D for maximum callus induction, and some scientists have found $100 \%$ callus induction in $3 \mathrm{mg} / \mathrm{L} 2,4-\mathrm{D}$ (Ather et al., 2009) and their results agree with our results because we also obtained the highest mass of callus at $3 \mathrm{mg} / \mathrm{L}$ 2,4-D. Ramanand et al. (2005) and Alam et al. (2003) observed maximum callus induction from leaf sheath explant at $4 \mathrm{mg} / \mathrm{L} 2,4-\mathrm{D}$. These results showed genotype influence on callus induction. A genotype-independent method for direct regeneration of sugarcane using the mid-rib segment as explant has been developed by Franklin et al. (2006).

In sugarcane cv. CO.671, regeneration of plants and direct somatic embryogenesis were reported by using leaf as explants (Manickavasagam and Ganapathi, 1998). They also found that 2,4-D at high concentrations favored callus induction and at low concentrations formed somatic embryo. MS medium supplemented with 2,4-D was found to induce callus with a greater capacity and potential for regeneration than MS medium with NAA (Alam et al., 2003). Among different concentrations, $3 \mathrm{mg} / \mathrm{L} 2,4-\mathrm{D}$ alone in callus induction medium is frequently used (Homhual et al., 2003). Scientists have reported numerous colors and texture of sugarcane callus on different media. Two callus types, one loose, friable and embryogenic and the other compact, white, nodular, and embryogenic were reported by Anbalagan et al. (2000). 
White, non-regenerative and green regenerative callus (Fitch and Moore, 1990) and compact and nodular callus forms (Escalona et al., 1995) have also been reported. We observed friable and globular embryogenic callus in genotype S-2003-us-359, compact and waxy/sticky, less embryogenic callus in S-2006-sp-30 and compact, hairy and waxy callus in the case of the S-2003-us-165 genotype. Sinha et al. (2000) reported compact, white embryogenic callus at low concentrations of auxin. CIM and genotypes are important factors and their interaction determines the final callus production. The trend seems true from our data. Callus production from genotype S-2003-us-165 also follows the trend but the total callus mass on all the CIM is too low and too hairy/ root-like for use in regeneration.

For regeneration, sucrose, BAP, and 2,4-D was used in different combinations. Two levels of sucrose $(30$ and $40 \mathrm{~g} / \mathrm{L})$, three levels of $2,4-\mathrm{D}(0.1,0.25$ and $0.5 \mathrm{mg} / \mathrm{L})$ and three levels of BAP $(0,0.25$ and $0.5 \mathrm{mg} / \mathrm{L})$ were studied in regeneration media, with basal MS salt in common. A low concentration of 2,4-D in regeneration media resulted in regeneration enhancement. In this experiment, regeneration media with $40 \mathrm{~g} / \mathrm{L}$ sucrose showed better performance as compared to media containing $30 \mathrm{~g} / \mathrm{L}$ sucrose. The effect of a high concentration of sucrose on in vitro culture of sugarcane has also been studied (Gonzalez-Morejon et al., 1988). Arginine has been found to be more effective not only in regeneration studies but also in callus induction (Falco et al., 2000). Germination of somatic embryos responds best on medium supplemented with gibberellic acid, sucrose, glutamic acid, and arginine. Media containing maltose and proline gave an increased mass of yellow, compact embryogenic calli among the different MS media supplemented with 2 $\mathrm{mg} / \mathrm{L}$ ABA, $560 \mathrm{mg} / \mathrm{L}$ proline, $30 \mathrm{~g} / \mathrm{L}$ maltose, and $2 \mathrm{mg} / \mathrm{L}$ 2,4-D (Himanshu et al., 2002). In our study, media containing a low concentration of 2,4-D $(0.1 \mathrm{mg} / \mathrm{L})$ and BAP $(0.25$ $\mathrm{mg} / \mathrm{L}$ ) performed better than others.

Maximum shoot regeneration was reported on MS medium supplemented with BAP, GA and vitamins by using axillary buds and shoot apices of sugarcane (Ather et al., 2009). For in vitro culture of sugarcane, different optimal range of macronutrients and plant regulators were determined by Cheong et al. (2009), and found that $60 \%$ of shoots were elongated on a medium containing BA, kinetin, GA3, and NAA. But other scientists, Behera and Sahoo (2009), documented that the MS medium supplemented with $2.5 \mathrm{mg} / \mathrm{L} \mathrm{2,4-D}$ gave the highest percentage of callus induction, but the best multiple shoot induction was obtained from medium containing BAP, NAA and when in vitro shoots were cultured on 1/2 MS medium supplemented with $3 \mathrm{mg} / \mathrm{L}$ NAA rooting was more profuse.

We obtained excellent regeneration on MS medium by lowering auxin concentration and this result was supported by the report of Kharinarain et al. (1996); they obtained maximum shooting by reducing auxin concentration in MS medium. Alam et al. (2003) also obtained good regeneration on MS medium containing low auxin and high cytokinin. Gill et al. (2004) obtained high shoot regeneration on medium containing $0.5 \mathrm{mg} / \mathrm{L} \mathrm{BAP}$. But in this study, media containing $0.25 \mathrm{mg} / \mathrm{L}$ BAP showed better regeneration response than media with $0.5 \mathrm{mg} / \mathrm{L} \mathrm{BAP}$. We compared the effects of different callus ages on regeneration and found it as one of the major factors in regeneration. We were not able to find this comparison in the literature. Perhaps we are the first ones to report this comparison. After selecting the best combination of regeneration medium with callus age, we performed RAPD analysis to confirm genetic stability, because in our study the genetic stability of the in vitro regenerated plant is very important. Change only due to our transgene is desired 
for us and not the change due to the tissue culture regime. Genetic stability was confirmed through plants on our selected medium combination, which had no genetic variation and this result also agrees with the results of the study by Sweby et al. (1994), which detected no genetic variation in calli grown on 2,4-D regime ranging from $1-5 \mathrm{mg} / \mathrm{L}$, over a 3-month period on culture.

In conclusion, it is possible to develop regeneration protocols, which produce genetically stable regenerants with high frequency. With improved medium combinations it may be possible to enhance the frequency of regeneration from embryogenic calli of genotypes S-2006-sp-30 and S-2003-us-165.

\section{ACKNOWLEDGMENTS}

We thank the Sugarcane Research Institute, AARI, Faisalabad, Pakistan, for support through provision of the material for culture. We also thank the UAF Directorate of Research, for support of the present study through "Promotion of Research".

\section{REFERENCES}

Alam R, Mannan SA, Karim Z and Amin MN (2003). Regeneration of sugarcane (Saccharum officinarum L.) Plantlet from callus. Pak. Sugar J. 18: 15-19.

Ali K and Afghan S (2001). Rapid multiplication of sugarcane through micropropagation technique. Pak. Sugar J. 16: 11-14.

Anbalagan S, Kalmani A and Sakila M (2000). In vitro propagation of sugarcane: nature of callus, direct regeneration, regeneration through callus and morphological variations. Res. Crops 2: 138-140.

Arencibia A, Molina PR, de la Riva G and Selman-Housein G (1995). Production of transgenic sugarcane (Saccharum officinarum L.) plants by intact cell electroporation. Plant Cell Rep. 14: 305-309.

Ather A, Khan S, Rehman A and Nazir M (2009). Optimization of the protocols for callus induction, regeneration and acclimatization of sugarcane cv. Thatta-10. Pak. J. Bot. 41: 815-820.

Barba R and Nickell LG (1969). Nutrition and organ differentiation in tissue cultures of sugarcane, a monocotyledon. Planta 89: 299-302.

Behera KK and Sahoo S (2009). Rapid in vitro micropropagation of sugarcane (Saccharum officinarum L. cv.-Nayana) through callus culture. Nat. Sci. 7: 1545-0740.

Brisibe EA, Miyake H, Taniguchi T and Maeda E (1994). Regulation of somatic embryogenesis in long-term callus cultures of sugarcane (Saccharum officinarum L.). New Phytol. 126: 301-307.

Cassells AC and Jones PW (1995). The Methodology of Plant Gene Manipulation. Criteria for Decision Making. Kluwer, Dordrecht, 124-129.

Cheong EJ, Mock R and Li R (2009). Optimizing culture medium for meristem tissue culture of several Saccharum species and commercial hybrids. J. Am. Soc. Sugar Cane Technol. 29: 149-165.

Chowdhury MKU and Vasil IK (1993). Molecular analysis of plants regenerated from embryogenic cultures of hybrid sugarcane cultivars (Saccharum spp.). Theor. Appl. Genet. 86: 181-188.

Cloutier S and Landry BS (1994). Molecular markers applied to plant tissue culture. In Vitro Cell. Dev. Biol. 30: 32-39.

Daniels J and Roach BT (1987). Taxonomy and Evolution. In: Sugarcane Improvement Through Breeding (Heinz DJ, ed.). Elsevier, Amsterdam, 7-84.

Devarumath RM, Doule RB, Kawar PG, Naikebawane SB, et al. (2007). Field performance and RAPD analysis to evaluate genetic fidelity of tissue culture raised plants vis-à-vis conventional setts derived plants of sugarcane. Sugar Tech 9: $17-22$.

Ellis J, Dodds P and Pryor T (2000). The generation of plant disease resistance gene specificities. Trends Plant Sci. 5: 373-379.

Escalona M, Castillo R, Concepcion O, Barroto CG, et al. (1995). Influence of two callus types on the establishment of cell suspensions in sugarcane (Sacchrum spp.). Centro Agricola 22: 63-70.

Falco MC, Tulmann Neto A and Ulian EC (2000). Transformation and expression of a gene for herbicide resistance in Brazilian sugarcane. Plant Cell Rep. 19: 1188-1194. 
Fitch MMM and Moore PH (1990). Comparison of 2,4-D and picloram for selection of long-term totipotent green callus cultures of sugarcane. Plant Cell Tiss. Org. Cult. 20: 157-163.

Franklin G, Arvinth S, Sheeba CJ, Kanchana M, et al. (2006). Auxin pretreatment promotes regeneration of sugarcane (Saccharum spp. hybrids) midrib segment explants. Plant Growth Regul. 50: 111-119.

Geijskes RJ, Wang LF, Lakshmanan P, McKeon MG, et al. (2003). Smartsette seedlings: tissue culture seed plants for the Australian sugar industry. Sugarcane Int. May/June 13-17.

Gill NK, Raman G and Gosal SS (2004). Factor enhancing somatic embryogenesis and plant regeneration sugarcane (Saccharum officinarum L.). Ind. J. Biotechnol. 3: 119-123.

Gonzalez-Morejon A, Ojito MC, Perez-Ponce J and Castellanos-Morales E (1988). Effect of high concentrations in vitro tissue culture in sugar cane (Saccharum spp.). Centro Agricola 15: 12-18.

Heinz DJ and Mee GWP (1969). Plant differentiation from callus tissue of Saccharum species. Crop Sci. 9: 346-348.

Himanshu S, Gill MS and Gosal SS (2002). Regulation of somatic embryogenesis and plant regeneration in sugarcane (Saccharum officinarum L.). Ind. J. Agri. Sci. 70: 181-183.

Ho WJ and Vasil IK (1983). Somatic embryogenesis in sugarcane (Saccharum officinarum L.) I. The morphology and physiology of callus formation and the ontogeny of somatic embryos. Protoplasma 118: 169-180.

Hogarth DM, Cox MC and Bull JK (1997). Sugarcane Improvement: Past Achievements and Future Prospects. Crop Improvement for the 21st Century. Research Signpost, Trivandrum, 29-56.

Homhual R, Jungjan S, Chatwachirawong P and Klinkong S (2003). Shoot Regeneration Derived from Cell Suspension of Sugarcane. Proceedings of the 4th Kasetar University Annual Conference, 3-7 February. Subject: Plant Agricultural Extension Communication, 485-495.

Irvine JE and Benda GTA (1987). Transmission of sugar cane diseases in plants derived by rapid regeneration from diseased leaf tissue. Sugar Cane 6: 14-16.

Keating BA and Wilson JR (1997). Intensive Sugarcane Production: Meeting the Challenge Beyond 2000. CAB International, Wallingford.

Kharinarain RP, Dolgikh VI and Guzhov YL (1996). Selection of media for mass regeneration of sugarcane plants from callus culture. Russ. J. Plant Physiol. 43: 97-100.

Larkin P and Scowcroft WR (1981). Somaclonal variation - a novel source of variability from cell cultures for plant improvement. Theor. Appl. Genet. 60: 197-214.

Liu MC (1981). In vitro Methods Applied to Sugarcane Improvement. In: Plant Tissue Culture: Methods and Applications in Agriculture (Thorpe TA, ed.). Academic Press, New York, 299-323.

Manickavasagam M and Ganapathi A (1998). Direct somatic embryogenesis and plant regeneration from leaf explants of sugarcane. Ind. J. Exp. Biol. 36: 832-835.

Palotta MA, Graham RD, Langridge P, Sparrow DHB, et al. (2000). RFLP mapping of manganese efficiency in barley. Theor. Appl. Genet. 101: 1100-1108.

Popelka JC and Altpeter F (2003). Evaluation of rye (Secale cereale L.) inbred lines and their crosses for tissue culture response and stable genetic transformation of homozygous rye inbred line L22 by biolistic gene transfer. Theor. Appl. Genet. 107: 583-590.

Ramanand KN, Subhanand N, Lal M and Sing SB (2005). Plantlet regeneration through leaf callus culture in sugarcane. Sugar Tech 8: 85-87.

Sinha H, Gill M and Gosal S (2000). Regulation of somatic embryogenesis and plant regeneration in sugarcane (Saccharum officinarum L.). Indian J. Agri. Sci. 70: 181-183.

Sweby DL, Huckett BI and Botha FC (1994). Minimizing somaclones variation in tissue cultures of sugarcane. Afr. Sugar. Technol. Ass. 68: 46-50.

Taylor PWJ, Geijskes JR, Ko HL, Fraser TA, et al. (1995). Sensitivity of random amplified polymorphic DNA analysis to detect genetic change in sugarcane during tissue culture. Theor. Appl. Genet. 90: 1169-1173.

Villalobos I (1987). Induccion y multipucacion de callos in vitro en tres cultivares comerciales de cana de azucar (Saccharnm spp.). Agron. Costarricense 11: 39-44. 